\title{
MULTI-CRITERIA DECISION MAKING IN CIVIL ENGINEERING. PART II - APPLICATIONS
}

\author{
Edmundas Kazimieras ZAVADSKAS ${ }^{\mathrm{a}}$, Jurgita ANTUCHEVIČIENÉ ${ }^{\mathrm{a}}$, Oleg KAPLIŃSKI ${ }^{\mathrm{b}}$ \\ ${ }^{a}$ Faculty of Civil Engineering, Vilnius Gediminas Technical University, \\ Saulètekio al. 11, 10223, Vilnius, Lithuania \\ ${ }^{b}$ Faculty of Architecture, Poznań University of Technology, Nieszawska 13C, 60-965 Poznań, Poland
}

Received 03 December 2015; accepted 28 December 2015

\begin{abstract}
The first part of the paper shortly presented developments of multi-criteria decision making (MCDM) methods and general data about their use in civil engineering, i.e. distribution by years, countries, authors and journals (Zavadskas et al. 2015). The current part of the paper focuses on MCDM application areas and domains. Web of Science Category "Engineering Civil" in Thomson Reuters Web of Science Core Collection academic data base is searched for a topic of MCDM. Only articles and review document types are selected for a detailed survey. They are grouped by Research Areas as presented in Web of Science data base. The most numerous research areas as Construction Building Technology, Transportation, Water Resources and Engineering (other topics) are analysed in detail. Research domains and solved problems are described as well as applied MCDM methods are highlighted. A total of 114 articles are reviewed, showing a wide possibilities of applying MCDM methods for civil engineering problems.
\end{abstract}

Keywords: MCDM, civil engineering, Web of Science, construction building technology, transportation, water resources, operations research.

\section{Introduction}

Multi-criteria decision making (MCDM) is applied in different areas of human activities. In the case of existence of at least two possible options, a person has to make a decision and to select the one which best meets his demands based on a number considered criteria. As it was mentioned in the first part of the paper, the origins of MCDM methods can be dated over 240 years ago. As an individual scientific discipline, it has been widely spreading since the middle of the previous century.

The formal decision making methods, with application of which the current paper is concerned, were intensively developed and applied to various engineering problems in recent decades. Many of the methods were developed outside the field of civil engineering and their applications are very diverse. Several useful reviews of these methods are provided in the books (Figueira et al. 2005; Ehrgott et al. 2010) as well journal articles (Wiecek et al. 2008; Zavadskas, Turskis 2011). Systematically classified information on MCDM methods and applications can be found in the newly published review (Mardani et al. 2015a).

Different types of review papers related to MCDM can be distinguished, i.e. reviews of developments and extensions of a particular method as well as on its applications (Behzadian et al. 2010, 2012; Balezentis A., Balezentis T. 2014), reviews of applications of different MCDM methods for a particular problem (Chai et al. 2013; Kabir et al. 2014; Govindan et al. 2015; Mardani

Corresponding author:

J. Antuchevičienè E-mail: jurgita.antucheviciene@vgtu.lt 
et al. 2015b). The current review paper aims at providing recent developments about the multiple-criteria decision making in the field of civil engineering. This field is extensive and plays an important role in the life of modern society. A very large number of decisions must be made through the life cycle of building. MCDM methods can facilitate making these decisions in a formal way. The presented survey provides numerous examples how can this be done in different research areas and domains of civil engineering.

\section{Initial survey and further research methodology}

Review is focused entirely on publications refereed in Thomson Reuters Web of Science Core Collection academic data base. As the data base is constantly updated, the current review is based on a state-of-art at a fixed date (November 27, 2015).

The Authors are interested in showing applications of MCDM methods for making decisions in civil engineering. Accordingly, Thomson Reuters Web of Science Core Collection academic data base is searched for papers involving a topic of MCDM and the search is refined for Web of Science Category "Engineering Civil". From the total amount of papers on a topic of MCDM (2494 papers), 5.57 percent are applications of the methods for civil engineering problems (a total of 139 documents). Next, only articles and review document types are selected for a detailed survey, while proceedings papers and book chapters are excluded. Accordingly, 114 journal papers, including 112 articles and 2 reviews are selected for a detailed review.

As the current part of paper focuses on applications, papers are grouped by Research Areas as pre- sented in Web of Science data base. Covered research areas are presented in Figure 1.

As can be seen from the data presented in the figure, the most numerous research areas are Water Resources (33 percent of applications), Construction Building Technology (20 percent) and Transportation (11 percent). These areas are independent and almost no overlapping. While it is noticed, that papers from other research areas are often assigned to several areas, i.e. the categories are overlapping. Interconnections of Research Areas are presented in Figure 2.

Further research is organized following the proposed block-scheme. Based on initial review of papers, four main Research Areas are determined, namely the most numerous areas as Construction Building Technology, Transportation, Water Resources, also other, specific topic of Engineering, that are not included in the mentioned areas. Environmental Sciences Ecology and Materials Science are not analysed as autonomous areas of applications. Materials Science is interconnected with Construction Building Technology and papers related to reconstruction or sustainable building are usually assigned to the both areas. While, papers belonging to Environmental Sciences Ecology overlap with two main areas, namely with the mentioned Construction Building Technology (sustainability or green building issues) and especially with Water Resources, covering ground water quality, wastewater and alike issues. The 6 papers from Geology Area cover groundwater issues and fully overlap with papers assigned to Water Resources. The only paper from 7 observed in Figure 1 analyses seismic retrofitting and is analysed assigning it to Construction Building Technology. Re-

\begin{tabular}{|c|c|c|c|}
\hline Field: Research Areas & Record Count & $\%$ of 114 & Bar Chart \\
\hline ENGINEERING & 114 & $100.000 \%$ & ש \\
\hline WATER RESOURCES & 38 & $33.333 \%$ & $\square$ \\
\hline CONSTRUCTION BUILDING TECHNOLOGY & 23 & $20.175 \%$ & 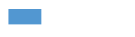 \\
\hline TRANSPORTATION & 13 & $11.404 \%$ & $\mathbf{\square}$ \\
\hline ENVIRONMENTAL SCIENCES ECOLOGY & 9 & $7.895 \%$ & $\mathbf{\square}$ \\
\hline MATERIALS SCIENCE & 9 & $7.895 \%$ & 口 \\
\hline COMPUTER SCIENCE & 7 & $6.140 \%$ & घ \\
\hline GEOLOGY & 7 & $6.140 \%$ & ! \\
\hline MATHEMATICS & 6 & $5.263 \%$ & 】 \\
\hline ENERGY FUELS & 4 & $3.509 \%$ & I \\
\hline BUSINESS ECONOMICS & 2 & $1.754 \%$ & I \\
\hline OPERATIONS RESEARCH MANAGEMENT SCIENCE & 2 & $1.754 \%$ & I \\
\hline AGRICULTURE & 1 & $0.877 \%$ & । \\
\hline METEOROLOGY ATMOSPHERIC SCIENCES & 1 & $0.877 \%$ & 1 \\
\hline OCEANOGRAPHY & 1 & $0.877 \%$ & 1 \\
\hline URBAN STUDIES & 1 & $0.877 \%$ & I \\
\hline
\end{tabular}

Fig. 1. Records by research areas 


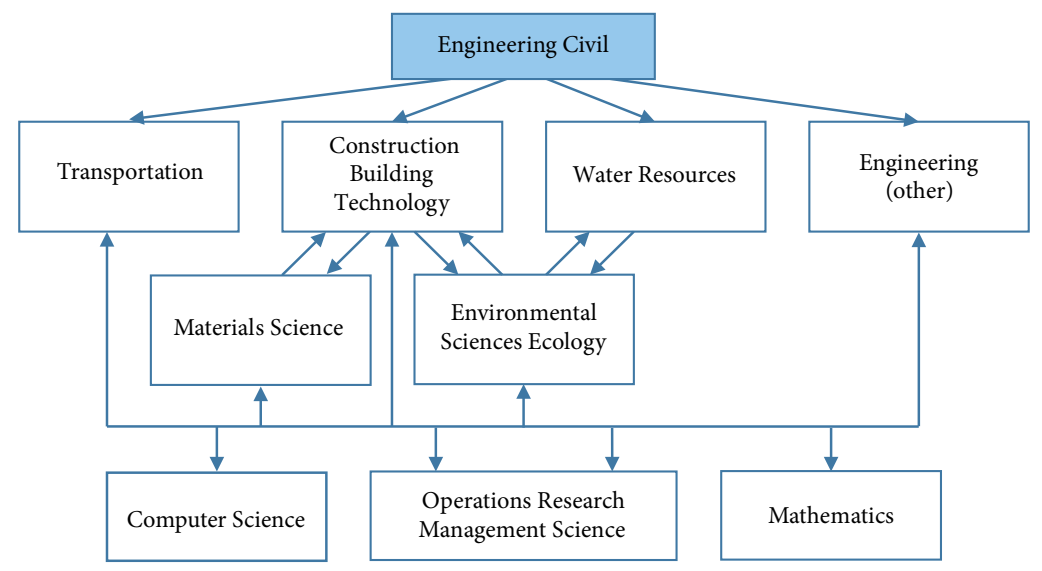

Fig. 2. Interconnections of research areas

search Areas of Computer Science, Mathematics and Operations Research Management Science are presented at the bottom of the scheme (Fig. 2), because they connect all the papers where MCDM methods and operations research techniques are applied for decision making.

Based on the above findings, the detailed review of papers is organized grouping all 114 journal articles by four main Research Areas. Findings are presented in the next Chapters.

\section{MCDM applications in Construction Building Technology}

After detailed review of the papers, 36 documents are assigned to the current research area. The number of documents does not mismatch with those presented in Figure 1, because a number of papers from area of Engineering are involved in the analysed research area after a detailed survey of their content and analysed problem.

The papers are grouped by research domains. Research domains for Construction Building Technology area are presented in Figure 3.

Firstly, two main domains are distinguished for new building, i.e. application of MCDM techniques for ranking construction technologies or decision support in problems related to building structures. Multicriteria approach is also applied for the next stages of building life cycle management: modernization or reconstruction, also demolition. The next important domain, especially in later years, is sustainable building and the more modern one - intelligent building. Also seismic retrofitting is separated as an independent domain due to numerous applications of the analysed

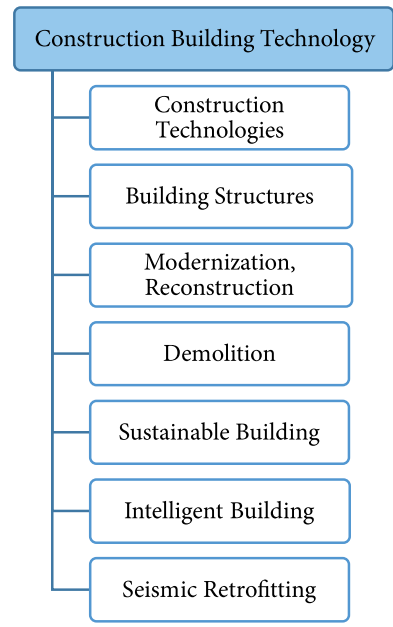

Fig. 3. Research domains in Construction Building Technology

methodology to a specific problem. Detailed review is presented, i.e. particular solved problems are described as well as applied MCDM methods are highlighted in Table 1. Description of MCDM methods by authors and years with references to initial sources are presented in the first part of the paper (history and stateof-art survey).

Different sustainability issues are analysed by applying a single MCDM method or aggregation of methods. Assessment of the whole sustainable building is made by Medineckiene et al. (2015), evaluation of separate structural element, i.e. concrete columns with emphasis on sustainability is presented by Pons and de la Fuente (2013), designing of optimal engineering systems for heating, ventilation and air conditioning is made by Soyguder and Alli (2009), urban planning issues are analysed by Wang et al. (2013). The most popular methods are observed to be AHP and ANP. They are applied in 5 papers from 7 ones. 
Table 1. MCDM applications by research domains in Construction Building Technology research area

\begin{tabular}{|c|c|c|}
\hline Research domain and the problem solved & MCDM method(s) applied & Publication \\
\hline \multicolumn{3}{|c|}{ Sustainable building } \\
\hline $\begin{array}{l}\text { Assessment of sustainable building, integrating LEED } \\
\text { criteria and MCDM methods }\end{array}$ & AHP, ARAS & Medineckiene et al. (2015) \\
\hline $\begin{array}{l}\text { Categorization of buildings based on their energy } \\
\text { performance }\end{array}$ & Fuzzy ANP & Kabak et al. (2014) \\
\hline $\begin{array}{l}\text { Integrated evaluation of concrete columns } \\
\text { sustainability }\end{array}$ & AHP, MIVES & Pons and de la Fuente (2013) \\
\hline $\begin{array}{l}\text { Planning protected areas in suburb with emphasis } \\
\text { on sustainability }\end{array}$ & AHP & Wang et al. (2013) \\
\hline $\begin{array}{l}\text { Analysing alternative dwellings considering a number } \\
\text { of criteria }\end{array}$ & Fuzzy games theory & Medineckiene et al. (2011) \\
\hline $\begin{array}{l}\text { Designing optimal heating, ventilation and air } \\
\text { conditioning system }\end{array}$ & $\begin{array}{l}\text { Artificial Neural Fuzzy Interface } \\
\text { System (ANFIS) }\end{array}$ & Soyguder and Alli (2009) \\
\hline $\begin{array}{l}\text { Environmental impact assessment and pollution } \\
\text { mitigation }\end{array}$ & AHP & Bose and Chakrabarti (2003) \\
\hline \multicolumn{3}{|c|}{ Intelligent building } \\
\hline $\begin{array}{l}\text { Assessment of intelligent buildings in an uncertain } \\
\text { environment }\end{array}$ & Fuzzy AHP, fuzzy TOPSIS & Kaya and Kahraman (2014) \\
\hline $\begin{array}{l}\text { Developing indicators and a framework for intelligent } \\
\text { building }\end{array}$ & AHP, ANP & Wong et al. (2008a) \\
\hline Evaluating intelligence of a building & AHP, ANP & Wong et al. (2008b) \\
\hline \multicolumn{3}{|c|}{ Construction Technologies } \\
\hline $\begin{array}{l}\text { Offered model for comprehensive assessment of } \\
\text { technologies }\end{array}$ & AHP, Permutation & Kildiene et al. (2014) \\
\hline $\begin{array}{l}\text { Selecting the most suitable solutions for ensuring } \\
\text { safety at a construction site }\end{array}$ & Entropy, WASPAS & $\begin{array}{l}\text { Dejus and Antucheviciene } \\
(2013)\end{array}$ \\
\hline $\begin{array}{l}\text { Sustainability assessment of building technologies; } \\
\text { an example of building a school }\end{array}$ & MIVES, AHP & Pons and Aguado (2012) \\
\hline Selecting a pile-column technology & TOPSIS, ARAS, COPRAS, AHP & Zavadskas et al. (2012) \\
\hline $\begin{array}{l}\text { Analyzing pile-column alternatives and selecting } \\
\text { the best one }\end{array}$ & Entropy, ARAS & Susinskas et al. (2011) \\
\hline $\begin{array}{l}\text { Selecting the best foundation installment variant } \\
\text { in aquiferous soil }\end{array}$ & ARAS & Zavadskas et al. (2010) \\
\hline \multicolumn{3}{|c|}{ Building Structures } \\
\hline $\begin{array}{l}\text { Comparison of thin walled steel structures, involving } \\
\text { structural, economic and environmental parameters }\end{array}$ & TOPSIS & Terracciano et al. (2015) \\
\hline $\begin{array}{l}\text { Assistance to designers choice in detailed building } \\
\text { design }\end{array}$ & AHP, CBA (Choosing by Advantages) & Arroyo et al. (2015) \\
\hline $\begin{array}{l}\text { Selecting structural systems for multi-housing project } \\
\text { with different stakeholders }\end{array}$ & ELECTRE III, PROMETHEE II & Balali et al. (2014) \\
\hline $\begin{array}{l}\text { Different shapes of thin walled structures compared } \\
\text { in accordance with multiple criteria }\end{array}$ & COPRAS & Tarlochan et al. (2013) \\
\hline $\begin{array}{l}\text { Estimating high-rise building structure systems during } \\
\text { the design stage }\end{array}$ & COPRAS-G & $\begin{array}{l}\text { Tamosaitiene and Gaudutis } \\
\text { (2013) }\end{array}$ \\
\hline \multicolumn{3}{|c|}{ Modernization, Reconstruction } \\
\hline $\begin{array}{l}\text { Ranking insulation material when retrofitting } \\
\text { historical brick buildings }\end{array}$ & TOPSIS grey & Zagorskas et al. (2014) \\
\hline $\begin{array}{l}\text { Efficiency of residential building modernization with } \\
\text { an emphasis on thermal insulation of external walls } \\
\text { is analyzed }\end{array}$ & SWARA, TODIM & Ruzgys et al. (2014) \\
\hline
\end{tabular}


End of Table 1

\begin{tabular}{|c|c|c|}
\hline Research domain and the problem solved & MCDM method(s) applied & Publication \\
\hline $\begin{array}{l}\text { Selecting the most appropriate modernization variant } \\
\text { of vernacular buildings }\end{array}$ & AHP, TOPSIS grey & Siozinyte et al. (2014) \\
\hline $\begin{array}{l}\text { Searching for the best compromise solution for } \\
\text { improving daylighting in a vernacular building }\end{array}$ & COPRAS, TOPSIS, WASPAS, AHP & $\begin{array}{l}\text { Siozinyte and Antucheviciene } \\
(2013)\end{array}$ \\
\hline $\begin{array}{l}\text { Ecological and economical assessment of dwellings } \\
\text { modernization }\end{array}$ & COPRAS, WASPAS, TOPSIS & Staniunas et al. (2013) \\
\hline Selecting materials for concrete repair & AHP & Do and Kim (2012) \\
\hline $\begin{array}{l}\text { Assessing owners preferences for residential buildings } \\
\text { renovation }\end{array}$ & SAW, MEW, COPRAS, AHP & $\begin{array}{l}\text { Medineckiene and Bjork } \\
(2011)\end{array}$ \\
\hline $\begin{array}{l}\text { Selecting optimal regeneration strategies and proper } \\
\text { localities for abandoned buildings }\end{array}$ & COPRAS-F & $\begin{array}{l}\text { Zavadskas and Antucheviciene } \\
(2007)\end{array}$ \\
\hline Ranking strategies for highway bridges rehabilitation & Fuzzy sets, MCDM, utility theory & Sobanjo et al. (1994) \\
\hline \multicolumn{3}{|c|}{ Demolition } \\
\hline $\begin{array}{l}\text { Finding the best demolition project; an example } \\
\text { of bridge demolition }\end{array}$ & AHP, ANP & Chen et al. (2014) \\
\hline \multicolumn{3}{|c|}{ Seismic Retrofitting } \\
\hline $\begin{array}{l}\text { Retrofitting with metal protection devices and } \\
\text { examining the effect of increasing a number of floors } \\
\text { in masonry buildings }\end{array}$ & TOPSIS, ELECTRE, VIKOR & $\begin{array}{l}\text { Formisano and Mazzolani } \\
(2015)\end{array}$ \\
\hline $\begin{array}{l}\text { Selecting the best seismic retrofit technique for } \\
\text { a concrete bridge }\end{array}$ & TOPSIS & Billah and Alam (2014) \\
\hline $\begin{array}{l}\text { Ranking of steel buildings according to their } \\
\text { damageability in seismic events }\end{array}$ & Fuzzy TOPSIS & Shahriar et al. (2012) \\
\hline $\begin{array}{l}\text { Selecting a strategy for seismic retrofitting of concrete } \\
\text { structure: comparative study of multiple criteria } \\
\text { approaches }\end{array}$ & $\begin{array}{l}\text { TOPSIS, WSM, VPM, VIKOR, } \\
\text { ELECTRE, PROMETHEE, MAUT }\end{array}$ & Caterino et al. (2009) \\
\hline $\begin{array}{l}\text { Comparing innovative seismic retrofitting possibilities } \\
\text { of a reinforced concrete building }\end{array}$ & TOPSIS & Caterino et al. (2008) \\
\hline
\end{tabular}

Three papers use fuzzy sets for decision in an uncertain environment. Medineckiene et al. (2015) applies hybrid method, including AHP for weighting of criteria and ARAS for ranking of alternatives. A similar aggregation of methods Kaya and Kahraman (2014) apply for assessment of intelligent buildings in an uncertain environment. They use fuzzy AHP and fuzzy TOPSIS.

In a domain of construction technologies, selecting a pile-column technology or foundations instalment alternatives are dominated issues. A large variety of methods for the current task are applied: AHP, Entropy, TOPSIS, ARAS, COPRAS. A model for comprehensive assessment of technologies applying AHP and Permutation method is offered by Kildiene et al. (2014). It is proposed to select the most suitable solution for ensuring safety at a construction site applying a novel method WASPAScombining with Entropy (Dejus, Antucheviciene 2013).

The single application of ELECTRE III, PRO-
METHEE II methods for selecting structural systems can be observed in a paper of Balali et al. (2014). High-rise building structure systems are estimated by applying COPRAS-G method (Tamosaitiene, Gaudutis 2013). It can be stated that application of grey numbers is rather rarer in the analysed area. It is interesting to mention, that two papers are devoted to comparison of thin walled steel structures in accordance with multiple criteria and applying two well-known methods TOPSIS and COPRAS (Terracciano et al. 2015; Tarlochan et al. 2013).

Modernisation and reconstruction domain partly overlaps with Materials Science research area. Ranking insulation material and evaluating modernisation efficiency for usual residential buildings or historical buildings is presented (Zagorskas et al. 2014; Ruzgys et al. 2014). Selecting materials for concrete repair is held by Do and Kim (2012). Interesting issue of vernacular building modernisation is analysed by Siozinyte et al. (2014) and Siozinyte, Antucheviciene (2013). 
As for the methods applied, it can be mentioned that no dominating method can be observed and a great variety of methods are applied: COPRAS, TOPSIS, WASPAS, SAW, MEW, TODIM, SWARA. It is worth to mention that COPRAS-F was firstly presented when selecting regeneration strategies for abandoned rural buildings (Zavadskas, Antucheviciene 2007).

Specific domain of seismic retrofitting problems is presented separately. The domain is very popular in scientific papers. As concerns MCDM methods, they are applied for steel buildings (Shahriar et al. 2012) or concrete structures (Billah and Alam 2014; Caterino et al. 2008, 2009) or masonry buildings (Formisano, Mazzolani 2015). The TOPSIS method is applied in all papers related to seismic retrofitting. Caterino et al. (2009) presented a comparative study of multiple criteria approaches for seismic issues, involving TOPSIS, WSM, VPM, VIKOR, ELECTRE, PROMETHEE and MAUT.

\section{MCDM applications in Transportation}

The next important and rather autonomous part of civil engineering applications constitute applications for transportation problems. Papers from Transportation Research Area are grouped by research domains as presented in Figure 4. The methods are applied for rational logistics decisions, for air and rail transpor-

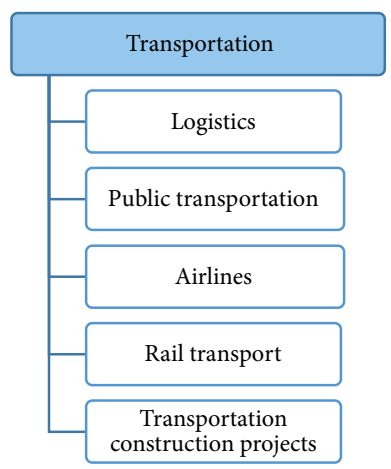

Fig. 4. Research domains in Transportation

Table 2. MCDM applications by research domains in Transportation research area

\begin{tabular}{|c|c|c|}
\hline Research domain and the problem solved & MCDM method(s) applied & Publication \\
\hline \multicolumn{3}{|c|}{ Logistics } \\
\hline $\begin{array}{l}\text { Assisting for a company for selecting the most } \\
\text { appropriate way of transportation between particular } \\
\text { locations }\end{array}$ & AHP & $\begin{array}{l}\text { Kumru M. and } \\
\text { Kumru P. Y. (2014) }\end{array}$ \\
\hline Selecting location in logistics and transportation & Fuzzy MCDM & Chou (2009) \\
\hline $\begin{array}{l}\text { Supporting development of a better freight } \\
\text { transportation system }\end{array}$ & Fuzzy AHP, Fuzzy MCDM & $\begin{array}{l}\text { Hanaoka and } \\
\text { Kunadhamraks (2009) }\end{array}$ \\
\hline \multicolumn{3}{|c|}{ Public transportation } \\
\hline $\begin{array}{l}\text { Customer satisfaction in public transportation is } \\
\text { measured and suggestions for improving } \\
\text { a transportation are made }\end{array}$ & Interval type-2 fuzzy sets, GRA, TOPSIS & Celik et al. (2013) \\
\hline $\begin{array}{l}\text { Applications of MCDM/MCDA in public } \\
\text { transportation }\end{array}$ & ELECTRE III & Zak (2011) \\
\hline $\begin{array}{l}\text { Analyzing environmental and social impacts } \\
\text { in a context of transportation demand }\end{array}$ & $\begin{array}{l}\text { AHP, CODASID(3) (a method based on } \\
\text { a complete concordance and discordance } \\
\text { analysis) }\end{array}$ & Tanadtang et al. (2005) \\
\hline \multicolumn{3}{|c|}{ Airlines } \\
\hline Evaluating service quality of airlines & VIKOR, GRA, interval-valued fuzzy sets & Kuo (2011) \\
\hline \multicolumn{3}{|l|}{ Rail transport } \\
\hline Risk identification in subway construction & AHP, IAHP (Improved AHP) & Li et al. (2013) \\
\hline Designing a train overhaul maintenance facility & Simulation optimization, MCDM & Um et al. (2011) \\
\hline Evaluating alternative rail transit plans & AHP & Gercek et al. (2004) \\
\hline \multicolumn{3}{|c|}{ Transportation construction projects } \\
\hline Creating and selecting highway alignment alternatives & AHP, GIS & Yakar and Celik (2014) \\
\hline $\begin{array}{l}\text { An empirical study of budget allocation for regional } \\
\text { transportation construction projects in Taiwan }\end{array}$ & $\begin{array}{l}\text { FAHP, the fuzzy multi-criteria grade } \\
\text { classification model (FMGCM) }\end{array}$ & Teng et al. (2010) \\
\hline Prioritization of construction projects for funding & AHP, TOPSIS & Shelton and Medina (2010) \\
\hline
\end{tabular}


tation solutions, and for assessing transportation construction projects.

It is worth to be mentioned that researchers have been applying MCDM methods for transportation solutions since 2004 (Table 2). The first application in the area in an article refereed in Web of Science data base is for evaluating alternative rail transit plans (Gercek et al. 2004). The AHP method is applied to compare the alternatives. The application in 2005 is for public transportation problems when searching the best combination of environmental and social impacts in a context of transportation demand with the help of AHP (Tanadtang et al. 2005).

The research showed that the crisp or fuzzy AHP method is the most often applied for logistics decisions when assisting for a company for to select the most appropriate way of transportation (Kumru M., Kumru P. Y. 2014) or to develop a better freight transportation system (Hanaoka and Kunadhamraks 2009).

Customers' satisfaction and transportation quality in public transportation are more difficult to evaluate by applying formal crisp methods, that's why fuzzy or grey numbers can be useful. Celik et al. (2013) apply Interval type-2 fuzzy sets, GRA and TOPSIS to measure passenger satisfaction, Kuo (2011) evaluates service quality of airlines with the help of VIKOR and GRA in combination with interval-valued fuzzy sets.

Additionally applications for transportation construction projects evaluation should be analysed. Shelton and Medina (2010) prioritizes construction projects for funding by applying the traditional combination of usual methods AHP and TOPSIS. Teng et al. (2010) analyses budget allocation for transportation construction projects in an uncertain and risky environment, integrating fuzzy sets theory with multiple criteria decision making and using FAHP as well as the fuzzy multi-criteria grade classification model.

\section{MCDM applications in Water Resources management}

The most numerous research area in civil engineering is Water Resources. One third of articles (33.33 percent) are assigned to the area (Fig. 1). As the area covers 38 papers, there is a need to categorize them by research domains. 7 research domains are distinguished as presented in Figure 5, starting from domestic water supply to wastewater, also separating specific areas as flood management or irrigation for agriculture purposes. As presented in Figure 2, a lot of papers assigned to Water Resources overlap with papers belong-

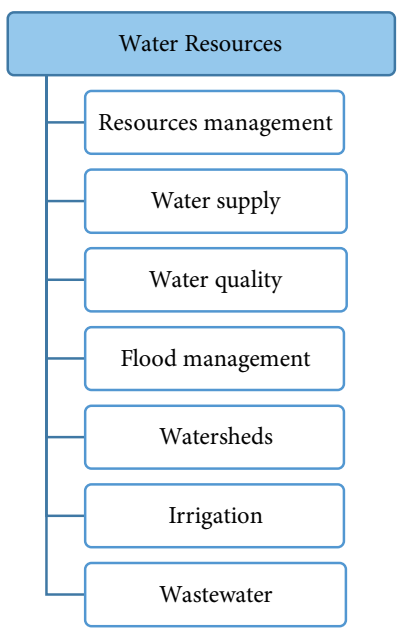

Fig. 5. Research domains in water resources

ing to Environmental Sciences Ecology research area, because problems related to protection of natural environment are analysed.

The papers are grouped by research domains and detailed by analysed problems and applied MCDM methods (Table 3). The research area is the most numerous, and the most widely spread by application years. The papers cover a period of 25 years, starting from 1991 up till now. The oldest applications of MCDM techniques for civil engineering problems are observed in the current area in WoS data base. The research showed that the oldest applications are based on outranking approaches as ELECTRE and PROMETHEE, also Composite programming (CP). Shafike et al. (1992) analyses fresh water supply and wastewater disposal and solves a problem of groundwater contamination by applying a combination of $\mathrm{CP}$, ELECTRE II and MCQA II. The latest extension of the method, namely ELECTRE III is used when selecting the most efficient alternatives for a long-term water supply (Netto et al. 1996), selecting the best strategies of irrigation (Raju, Duckstein 2004), etc.

The subsequent papers present several new developments of methods with application examples in water resources management problems. Zarghami and Szidarovszky (2009) presents new approach SFOWA: Ordered Weighted Averaging (OWA) operator with stochastic-fuzzy modelling, and solves an example of recourses management of Central Tisza River in Hungary. Roozbahani et al. (2012) suggest PROMETHEE with Precedence Order in the Criteria (PPOC) with application to group water management decisions for urban water supply systems. Li et al. (2009) presents a new optimization method using fuzzy pattern recognition for optimizing water supply network. 
Table 3. MCDM applications by research domains in Water Resources research area

\begin{tabular}{|c|c|c|}
\hline Research domain and the problem solved & MCDM method(s) applied & Publication \\
\hline \multicolumn{3}{|c|}{ Resources Management } \\
\hline $\begin{array}{l}\text { Spatial multiple criteria decision-making } \\
\text { model to analyze water demand and different } \\
\text { management possibilities }\end{array}$ & TOPSIS, MODM & $\begin{array}{l}\text { Rousta and Araghinejad } \\
\text { (2015) }\end{array}$ \\
\hline $\begin{array}{l}\text { Solving water export conflict through social } \\
\text { decision making under uncertainty }\end{array}$ & $\begin{array}{l}\text { Ranking, Voting, Borda, Pairwise comparison, } \\
\text { Majoritarian Compromise, Monte-Carlo }\end{array}$ & Madani et al. (2014) \\
\hline $\begin{array}{l}\text { Potential groundwater allocation zones are } \\
\text { predicted combining multicriteria analysis } \\
\text { and GIS }\end{array}$ & AHP & Kumar et al. (2014) \\
\hline $\begin{array}{l}\text { Measuring performance of different water } \\
\text { resources management alternatives }\end{array}$ & $\mathrm{CP}$ & Geng and Wardlaw (2013) \\
\hline $\begin{array}{l}\text { Water reservoirs operations involving } \\
\text { uncertainties }\end{array}$ & $\begin{array}{l}\text { Fuzzy-state stochastic dynamic programming } \\
\text { (FSDP), MCDM }\end{array}$ & Akbari et al. (2011) \\
\hline $\begin{array}{l}\text { Supporting managers in water resources } \\
\text { operations; example of Karun water reservoirs }\end{array}$ & Fuzzy TOPSIS & Afshar et al. (2011) \\
\hline Allocating potential groundwater resources & $\begin{array}{l}\text { AHP integrated with Remote sensing (RS) and } \\
\text { geographic information system (GIS) }\end{array}$ & Machiwal et al. (2011) \\
\hline $\begin{array}{l}\text { Recourses management; an example of } \\
\text { Central Tisza river in Hungary }\end{array}$ & $\begin{array}{l}\text { SFOWA: Ordered Weighted Averaging (OWA) } \\
\text { operator, stochastic-fuzzy modelling }\end{array}$ & $\begin{array}{l}\text { Zarghami and Szidarovszky } \\
(2009)\end{array}$ \\
\hline $\begin{array}{l}\text { Adequacy of models and techniques for } \\
\text { ground-water management are discussed }\end{array}$ & $\begin{array}{l}\text { Compromise programming (CP), ELECTRE III, } \\
\text { multiattribute utility function, UTA }\end{array}$ & Duckstein et al. (1994) \\
\hline $\begin{array}{l}\text { Testing effectiveness of several techniques } \\
\text { for water resource management task }\end{array}$ & $\begin{array}{l}\text { MATS-PC, EXPERT CHOICE, ARIADNE, } \\
\text { ELECTRE }\end{array}$ & Goicoechea et al. (1992) \\
\hline \multicolumn{3}{|c|}{ Water Supply } \\
\hline $\begin{array}{l}\text { Analysis of water users and inter-basin water } \\
\text { transfer systems }\end{array}$ & AHP, ANP, ER, TOPSIS, PROMETHEE II & $\begin{array}{l}\text { Abed-Elmdoust and } \\
\text { Kerachian (2014) }\end{array}$ \\
\hline $\begin{array}{l}\text { Group water management decisions for urban } \\
\text { water supply systems }\end{array}$ & $\begin{array}{l}\text { PROMETHEE with Precedence Order in the } \\
\text { Criteria (PPOC) }\end{array}$ & Roozbahani et al. (2012) \\
\hline Optimizing water supply network & $\begin{array}{l}\text { A new optimization method using fuzzy pattern } \\
\text { recognition }\end{array}$ & Li et al. (2009) \\
\hline Optimizing water distribution networks & AHP, GA (genetic algorithm) & $\begin{array}{l}\text { Vamvakeridou-Lyroudia } \\
\text { et al. }(2006)\end{array}$ \\
\hline $\begin{array}{l}\text { Evaluating different scenarios of water } \\
\text { industry privatization in Korea }\end{array}$ & WSM & Choi and Park (2001) \\
\hline $\begin{array}{l}\text { Designing alternatives of a system for a long- } \\
\text { term water supply and selecting the most } \\
\text { efficient ones }\end{array}$ & ELECTRE III & Netto et al. (1996) \\
\hline \multicolumn{3}{|c|}{ Water Quality } \\
\hline $\begin{array}{l}\text { Assessment of drinking water quality through } \\
\text { monitoring different parameters in water } \\
\text { distribution network }\end{array}$ & $\begin{array}{l}\text { Fuzzy rule-based system, Fuzzy Dempster- } \\
\text { Shafer, AHP }\end{array}$ & Aghaarabi et al. (2014) \\
\hline $\begin{array}{l}\text { Improving water quality through selecting } \\
\text { the best agricultural practices }\end{array}$ & A-IFS, MCDM (SAW) & $\begin{array}{l}\text { Hernandez and Uddameri } \\
(2010)\end{array}$ \\
\hline $\begin{array}{l}\text { Identifying various components of } \\
\text { hydrological vulnerability and supporting } \\
\text { residential decisions }\end{array}$ & AHP, ELECTRE II & Chung and Lee (2009) \\
\hline $\begin{array}{l}\text { Assisting stakeholders to select the best } \\
\text { technology for groundwater remediation }\end{array}$ & PROMETHEE II & Khelifi et al. (2006) \\
\hline
\end{tabular}


End of Table 3

\begin{tabular}{|c|c|c|}
\hline Research domain and the problem solved & MCDM method(s) applied & Publication \\
\hline $\begin{array}{l}\text { Integrating model for managing water } \\
\text { resources and controlling water pollution }\end{array}$ & AHP, SAW & Karamouz et al. (2003) \\
\hline $\begin{array}{l}\text { Nitrate contamination is analyzed and risk } \\
\text { for human health prevention alternative are } \\
\text { evaluated }\end{array}$ & Fuzzy MCDM & Lee at al. (1994) \\
\hline $\begin{array}{l}\text { Solving problem of groundwater } \\
\text { contamination, involving fresh water supply } \\
\text { and wastewater disposal }\end{array}$ & $\begin{array}{l}\text { Compromise programming (CP), ELECTRE II, } \\
\text { MCQA II }\end{array}$ & Shafike et al. (1992) \\
\hline $\begin{array}{l}\text { Designing network for ground water } \\
\text { monitoring }\end{array}$ & Compromise programming $(\mathrm{CP})$ & Woldt and Bogardi (1992) \\
\hline \multicolumn{3}{|c|}{ Flood Management } \\
\hline $\begin{array}{l}\text { Selecting the best management strategy before } \\
\text { and after a river flood; comparing different } \\
\text { MCDM methods }\end{array}$ & $\begin{array}{l}\text { ELECTRE I, ELECTRE III, SAW, CP, VIKOR, } \\
\text { TOPSIS, M-TOPSIS, AHP }\end{array}$ & $\begin{array}{l}\text { Chitsaz and Banihabib } \\
(2015)\end{array}$ \\
\hline $\begin{array}{l}\text { Assessment of flood management strategies } \\
\text { involving analysis of consequences of } \\
\text { inundation velocity and duration }\end{array}$ & $\begin{array}{l}\text { Spatial MCDM (SMCDM), Spatial Compromise } \\
\text { Programming (SCP). }\end{array}$ & Ahmadisharaf et al. (2015) \\
\hline $\begin{array}{l}\text { Assessing alternative solutions for flood } \\
\text { damage reduction. }\end{array}$ & PROMETHEE & Su and Tung (2014) \\
\hline $\begin{array}{l}\text { New technique for flood management is } \\
\text { developed when integrating MCDM and GIS }\end{array}$ & Spatial Monte Carlo Analysis (SMCA) & Qi et al. (2013) \\
\hline $\begin{array}{l}\text { Supporting decisions in flood management } \\
\text { under uncertainty }\end{array}$ & ANP, remote sensing, GIS & Levy (2005) \\
\hline $\begin{array}{l}\text { Techniques for fitting floods are ranked by } \\
\text { applying MCDM methods }\end{array}$ & $\begin{array}{l}\text { Composite programming, ELECTRE, MCQA, } \\
\text { fuzzy sets }\end{array}$ & Duckstein et al. (1991) \\
\hline \multicolumn{3}{|c|}{ Watersheds } \\
\hline $\begin{array}{l}\text { Analysing watershed vulnerability and } \\
\text { restrictions for land-use activities }\end{array}$ & Modified VIKOR & Chang and Hsu (2011) \\
\hline Ecological risk management in watershed & $\begin{array}{l}\text { FMCGDM model based on modified Borda } \\
\text { scoring method }\end{array}$ & Hao and Chen (2010) \\
\hline $\begin{array}{l}\text { Ranking watershed resources management } \\
\text { alternatives applying different techniques and } \\
\text { searching for the most effective technique }\end{array}$ & 15 techniques & Tecle (1992) \\
\hline \multicolumn{3}{|c|}{ Irrigation } \\
\hline $\begin{array}{l}\text { An economic framework for allocation of } \\
\text { water resources }\end{array}$ & Entropy, MCDM & Karamouz et al. (2014) \\
\hline Ranking of alternatives for irrigation planning & $\begin{array}{l}\text { Data Envelopment Analysis (DEA); } \\
\text { PROMETHEE, EXPROM }\end{array}$ & Raju and Kumar (2006) \\
\hline $\begin{array}{l}\text { Selecting the best strategies in irrigation area } \\
\text { considering environmental, economic and } \\
\text { social criteria }\end{array}$ & ELECTRE III & Raju and Duckstein (2004) \\
\hline $\begin{array}{l}\text { Evaluating management alternatives for } \\
\text { irrigation with an emphasis on sustainable } \\
\text { development subsystems }\end{array}$ & $\begin{array}{l}\text { PROMETHEE-2, EXPROM-2, ELECTRE III, } \\
\text { ELECTRE IV, and Compromise Programming } \\
\text { (CP) }\end{array}$ & Raju et al. (2000) \\
\hline \multicolumn{3}{|c|}{ Wastewater } \\
\hline $\begin{array}{l}\text { Analysis of wastewater allocation scenarios, } \\
\text { considering different climate change } \\
\text { possibilities }\end{array}$ & TOPSIS & Kim et al. (2015) \\
\hline
\end{tabular}


A distinctive feature of the current research is using Geographical Information Systems (GIS) in combination with MCDM techniques for problems related to location. Kumar et al. (2014) predicts potential groundwater allocation zones combining AHP and GIS. Machiwal et al. (2011) supports allocating groundwater resources, integrating the mentioned AHP, GIS and Remote sensing (RS). The same combination of three techniques is applied by Levy (2005) for supporting decisions in flood management. Qi et al. (2013) suggests a new technique for flood management when integrating multiple criteria analysis and GIS, called Spatial Monte Carlo Analysis (SMCA).

The second distinctive feature from the methodological point of view is that there are several papers applying a number of MCDM methods and comparing the results. The latest researches involve Chitsaz and Banihabib (2015) compare the applicability of different MCDM methods for selecting the best river flood management strategy and applies ELECTRE I, ELECTRE III, SAW, CP, VIKOR, TOPSIS, M-TOPSIS and AHP. Madani et al. (2014) solve water export conflict through using Ranking, Voting, Borda, Pairwise comparison, Majoritarian Compromise and Monte-Carlo approaches. Even in 2000 Raju et al. (2000) evaluated management alternatives for irrigation using PROMETHEE-2, EXPROM-2, ELECTRE III, ELECTRE IV and CP. Tecle (1992) applies 15 different techniques for ranking watershed resources management alternatives and searches for the most effective technique.

\section{MCDM applications in other areas of engineering}

The last group of papers is divided into three independent research domains (Fig. 6), characterized by interesting applications (Table 4). Separately are reviewed papers analysing technological or management problems of building infrastructure objects (Kabir et al. 2014). The methods are successfully applied for

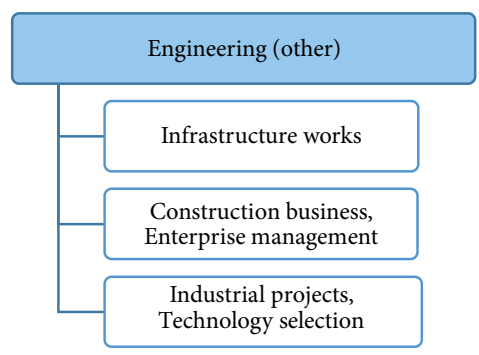

Fig. 6. Other research domains in engineering construction business planning and construction enterprise management. The numerous applications are observed for technology selection for different industrial projects.

Construction business and enterprise management domain covers procurement, contractor selection, assessing success of construction projects or selecting management strategies in construction enterprises. AHP method as a single technique or aggregated with other approaches is still popular in the domain: Lin et al. (2015) ranks procurement methods for public building maintenance, Zavadskas et al. (2014) evaluates construction project performance by aggregating AHP and MEW. Zavadskas et al. (2011) determine management strategies of construction enterprises using SWOT and select the best strategy applying AHP and permutation method. Chou et al. (2010) developed a new approach of AHP with Monte Carlo simulation (MCS) for assessing project performance through earned value management.

Technology selection for industrial project domain covers different interesting and useful applications. A large variety of applied methods is also observed. Kursunoglu and Onder (2015) select the most suitable fan for ventilation of mines by applying well known AHP method. Emovon et al. (2015) analyses marine machinery systems and suggests a novel methodology for assessing their risk using VIKOR and CP. Bagocius et al. (2014) selects the best location and the most suitable type of wind turbine by WASPAS technique. Fuzzy AHP and fuzzy TOPSIS are applied for selecting a boring machine for tunnelling (YazdaniChamzini and Yakhchali 2012) and for evaluating shaft sinking operations and selecting the most appropriate one (Lashgari et al. 2011). Concrete pumps selection with the help of ELECTRE III is performed by Ulubeyli and Kazaz (2009).

\section{Conclusions}

Limiting the research on Thomson Reuters Web of Science Core Collection academic data base and Web of Science Category "Engineering Civil", 114 papers (articles and review) are included in the detailed review of MCDM applications for civil engineering problems.

When grouping papers by Research Areas following Web of Science distribution, the four main Research Areas are identified, namely Construction Building Technology, Transportation, Water Resourc- 
Table 4. MCDM applications by research domains in other research areas of Engineering

\begin{tabular}{|c|c|c|}
\hline Research domain and the problem solved & MCDM method(s) applied & Publication \\
\hline \multicolumn{3}{|c|}{ Infrastructure works } \\
\hline $\begin{array}{l}\text { Selecting the best construction method of collection } \\
\text { systems for urban storm water }\end{array}$ & $\begin{array}{l}\text { FAHP and CP (Compromise } \\
\text { Programming) }\end{array}$ & Ebrahimian et al. (2015) \\
\hline $\begin{array}{l}\text { An approach for health monitoring of } \\
\text { telecommunication towers, based on group visual } \\
\text { assessment }\end{array}$ & Fuzzy TOPSIS & Verma et al. (2015) \\
\hline $\begin{array}{l}\text { Selecting intelligent sensors for health monitoring } \\
\text { of bridges using }\end{array}$ & SWARA, WASPAS & Bitarafan et al. (2014) \\
\hline $\begin{array}{l}\text { An overview of MCDM applications for } \\
\text { infrastructure problems }\end{array}$ & $\begin{array}{l}\text { WSM, WPM, CP, AHP, ELECTRE, } \\
\text { TOPSIS, AHP, VIKOR }\end{array}$ & Kabir et al. (2014) \\
\hline Evaluation of parking infrastructure problems & SAW, TOPSIS, COPRAS, AHP & Palevicius et al. (2013) \\
\hline \multicolumn{3}{|c|}{ Construction business, enterprise management } \\
\hline $\begin{array}{l}\text { Evaluating and prioritizing procurement methods } \\
\text { for public building maintenance }\end{array}$ & AHP & Lin et al. (2015) \\
\hline $\begin{array}{l}\text { Aggregated evaluation of construction project } \\
\text { performance }\end{array}$ & AHP, MEW & Zavadskas et al. (2014) \\
\hline $\begin{array}{l}\text { Accumulating success criteria, comparing and } \\
\text { ranking success of construction projects }\end{array}$ & M-TOPSIS & Pinter and Psunder (2013) \\
\hline Assessing industrial projects prior to investment & WSM, Simos' procedure & Marzouk et al. (2013) \\
\hline $\begin{array}{l}\text { Selection of projects and project portfolio formation } \\
\text { in contractor firms }\end{array}$ & Fuzzy SAW & $\begin{array}{l}\text { Abbasianjahromi and Rajaie } \\
(2012)\end{array}$ \\
\hline $\begin{array}{l}\text { Determining and selecting management strategies } \\
\text { in construction enterprises }\end{array}$ & SWOT, AHP, permutation method & Zavadskas et al. (2011) \\
\hline $\begin{array}{l}\text { System for assessing project performance through } \\
\text { earned value management }\end{array}$ & $\begin{array}{l}\text { AHP with Monte Carlo simulation } \\
\text { (MCS) }\end{array}$ & Chou et al. (2010) \\
\hline Decision support for strategic partnering & ANP & Cheng and Li (2007) \\
\hline \multicolumn{3}{|c|}{ Industrial projects, technology selection } \\
\hline $\begin{array}{l}\text { Selecting the most suitable fan for ventilation } \\
\text { of mines }\end{array}$ & AHP & Kursunoglu and Onder (2015) \\
\hline $\begin{array}{l}\text { Novel methodology for assessing the risk of marine } \\
\text { machinery systems }\end{array}$ & VIKOR, CP & Emovon et al. (2015) \\
\hline $\begin{array}{l}\text { Selecting the most suitable type of wind turbine } \\
\text { and the best location in offshore area }\end{array}$ & WASPAS & Bagocius et al. (2014) \\
\hline Selecting boring machine for tunnelling & Fuzzy AHP, Fuzzy TOPSIS & $\begin{array}{l}\text { Yazdani-Chamzini and } \\
\text { Yakhchali (2012) }\end{array}$ \\
\hline $\begin{array}{l}\text { Selecting optimal strategy for recycling in solar } \\
\text { energy industry }\end{array}$ & ANP & Shiue and Li (2012) \\
\hline $\begin{array}{l}\text { Evaluating shaft sinking operations and selecting } \\
\text { the most appropriate one }\end{array}$ & Fuzzy AHP, Fuzzy TOPSIS & Lashgari et al. (2011) \\
\hline $\begin{array}{l}\text { Construction equipment selection with an example } \\
\text { of concrete pumps }\end{array}$ & ELECTRE III & Ulubeyli and Kazaz (2009) \\
\hline Measuring industrial risk & AHP & Heler (2006) \\
\hline $\begin{array}{l}\text { Integrating preferences in environmental risk } \\
\text { analysis; an example of oil and gas industry }\end{array}$ & Fuzzy AHP & Tesfamariam and Sadiq (2006) \\
\hline Effective managing of hydropower reservoirs & AHP & Karamouz et al. (2005) \\
\hline
\end{tabular}


es and Engineering (other topics, not included in the previous three areas). Papers, included to Materials Science and Environmental Sciences Ecology are not analysed separately, because these document are also assigned to one of the previously mentioned main areas, i.e. usually Materials Science overlaps with Construction Building Technology, and Environmental Sciences Ecology overlaps with Water Resources.

It was found that Construction Building Technology with applications of MCDM techniques covers seven research domains. Construction technologies are selected or Building structures are assessed using the multi-criteria approach. Decisions are supported by MCDM in the whole building life cycle, involving Modernization, Reconstruction and even Demolition issues. Also two very modern domains are covered, namely Sustainable building and Intelligent Building. As an independent domain, Seismic retrofitting of steel buildings or concrete structures can be mentioned. From the methodological side, non-compensatory AHP and ANP methods are used for measurement of intangible criteria when assessing sustainability or evaluating intelligent buildings. Other problems, related to technologies or structures, usually are solved by applying compensatory methods TOPSIS, ARAS, COPRAS, VIKOR, WASPAS.

In Transportation Research Area applications for transportation construction problems, effective decision-making in logistics and assessing transportation problems are observed. Researchers have been applying MCDM methods for transportation solutions since 2004. The earliest applications use the most popular AHP and TOPSIS methods. In the latest papers, covering customer satisfaction or other stakeholders' interests, modifications of techniques by applying fuzzy sets or grey relations appear.

The most numerous research area involving MCDM applications in civil engineering is Water Resources, covering one third of analysed articles. The articles are grouped into 7 research domains, involving water supply, wastewater, floods management, etc. The oldest applications are also observed in the current area and in different domains. The papers published in 1991 and 1992 use MCDM methods for ranking techniques for fitting floods, ranking watershed resources management alternatives, solving problems of groundwater contamination and monitoring. The research showed that the oldest applications are based on outranking approaches as ELECTRE and PROMETHEE.
The later papers present several new developments of methods with application examples in water resources management problems. A distinctive feature of the current domain is using Geographical Information Systems (GIS) in combination with MCDM techniques for problems related to location.

The last group of papers covers three independent research domains, characterized by interesting applications, i.e. construction business planning and enterprise management, infrastructure projects and industrial projects. Construction management domain involves assessing success of construction projects or selecting management strategies. AHP method as a single technique or aggregated with other approaches is the most popular decision support tool in the domain. While, in contrast, a great variety of compensatory and non-compensatory outranking MCDM methods for infrastructure problems are applied. Technology selection for industrial project domain also covers different applications in mining, tunnelling, marine, energy industries. For decisions in an uncertain and risky environment a combination of fuzzy AHP and fuzzy TOPSIS are most common in the domain.

\section{References}

Abbasianjahromi, H.; Rajaie, H. 2012. Developing a project portfolio selection model for contractor firms considering the risk factor, Journal of Civil Engineering and Management 18(6): 879-889.

http://dx.doi.org/10.3846/13923730.2012.734856

Abed-Elmdoust, A.; Kerachian, R. 2014. Evaluating the relative power of water users in inter-basin water transfer systems, Water Resources Management 28(2): 495-509. http://dx.doi.org/10.1007/s11269-013-0495-9

Afshar, A.; Marino, M. A.; Saadatpour, M.; Afshar, A. 2011. Fuzzy TOPSIS multi-criteria decision analysis applied to Karun reservoirs system, Water Resources Management 25(2): 545-563. http://dx.doi.org/10.1007/s11269-010-9713-x

Aghaarabi, E.; Aminravan, F.; Sadiq, R.; Hoorfar, M.; Rodriguez, M. J.; Najjaran, H. 2014. Comparative study of fuzzy evidential reasoning and fuzzy rule-based approaches: An illustration for water quality assessment in distribution networks, Stochastic Environmental Research and Risk Assessment 28(3): 655-679. http://dx.doi.org/10.1007/s00477-013-0780-4

Ahmadisharaf, E.; Kalyanapu, A. J.; Chung, E.-S. 2015. Evaluating the effects of inundation duration and velocity on selection of flood management alternatives using multi-criteria decision making, Water Resources Management 29(8): 2543-2561.

Akbari, M.; Afshar, A.; Mousavi, S. J. 2011. Stochastic multiobjective reservoir operation under imprecise objectives: multicriteria decision-making approach, Journal of Hydroinformatics 13(1): 110-120. 
Arroyo, P.; Tommelein, I. D.; Ballard, G. 2015. Comparing AHP and CBA as decision methods to resolve the choosing problem in detailed design, Journal of Construction Engineering and Management 141(1).

http://dx.doi.org/10.1061/(ASCE)CO.1943-7862.0000915

Bagocius, V.; Zavadskas, E. K.; Turskis, Z. 2014. Multi-person selection of the best wind turbine based on the multi-criteria integrated additive-multiplicative utility function, Journal of Civil Engineering and Management 20(4): 590-599. http://dx.doi.org/10.3846/13923730.2014.932836

Balali, V.; Zahraie, B.; Roozbahani, A. 2014. Integration of ELECTRE III and PROMETHEE II decision-making methods with an interval approach: Application in selection of appropriate structural systems, Journal of Computing in Civil Engineering 28(2): 297-314. http://dx.doi.org/10.1061/(ASCE)CP.1943-5487.0000254

Balezentis, A.; Balezentis, T. 2014. A survey on development and applications of the multi-criteria decision making method MULTIMOORA, Journal of Multi-Criteria Decision Analysis 21(3-4): 209-222. http://dx.doi.org/10.1002/mcda.1501

Behzadian, M.; Kazemzadeh, R. B.; Albadvi, A.; Aghdasi, M. 2010. PROMETHEE: a comprehensive literature review on methodologies and applications, European Journal of Operational Research 200(1): 198-215.

http://dx.doi.org/10.1016/j.ejor.2009.01.021

Behzadian, M.; Otaghsara, S. K.; Yazdani, M.; Ignatius, J. 2012. A state-of the-art survey of TOPSIS applications, Expert Systems with Applications 39(17): 13051-13069. http://dx.doi.org/10.1016/j.eswa.2012.05.056

Billah, A. H. M. M.; Alam, M. S. 2014. Performance-based prioritisation for seismic retrofitting of reinforced concrete bridge bent, Structure and Infrastructure Engineering 10(8): 929-949. http://dx.doi.org/10.1080/15732479.2013.772641

Bitarafan, M.; Zolfani, S. H.; Arefi, S. L.; Zavadskas, E. K. 2014. Evaluation of real-time intelligent sensors for structural health monitoring of bridges based on SWARA-WASPAS; A case in Iran, Baltic Journal of Road and Bridge Engineering 9(4): 333-340. http://dx.doi.org/10.3846/bjrbe.2014.40

Bose, P.; Chakrabarti, R. 2003. Application of optimized multicriteria decision-making in an environmental impact assessment study, Civil Engineering and Environmental Systems 20(1): 31-48. http://dx.doi.org/10.1080/10286600302230

Caterino, N.; Iervolino, I.; Manfredi, G.; Cosenza, E. 2008. Multi-criteria decision making for seismic retrofitting of RC structures, Journal of Earthquake Engineering 12(4): 555-583. http://dx.doi.org/10.1080/13632460701572872

Caterino, N.; Iervolino, I.; Manfredi, G.; Cosenza, E. 2009. Comparative analysis of multi-criteria decision-making methods for seismic structural retrofitting, Computer-Aided Civil and Infrastructure Engineering 24(6): 432-445. http://dx.doi.org/10.1111/j.1467-8667.2009.00599.x

Celik, E.; Bilisik, O. N.; Erdogan, M.; Gumus, A. T.; Baracli, H. 2013. An integrated novel interval type-2 fuzzy MCDM method to improve customer satisfaction in public transportation for Istanbul, Transportation Research Part E-Logistics and Transportation Review 58: 28-51. http://dx.doi.org/10.1016/j.tre.2013.06.006

Chai, J.; Liu, J. N. K.; Ngai, E. W. T. 2013. Application of decision-making techniques in supplier selection: A systematic review of literature, Expert Systems with Applications 40(10): 3872-3885. http://dx.doi.org/10.1016/j.eswa.2012.12.040
Chang, C.-L.; Hsu, C.-H. 2011. Applying a modified VIKOR method to classify land subdivisions according to watershed vulnerability, Water Resources Management 25(1): 301-309. http://dx.doi.org/10.1007/s11269-010-9700-2

Chen, Z.; Abdullah, A. B.; Anumba, C. J.; Li, H. 2014. ANP experiment for demolition plan evaluation, Journal of Construction Engineering and Management 140(2). http://dx.doi.org/10.1061/(ASCE)CO.1943-7862.0000791

Cheng, E. W. L.; Li, H. 2007. Application of ANP in process models: an example of strategic partnering, Building and Environment 42(1): 278-287. http://dx.doi.org/10.1016/j.buildenv.2005.07.031

Chitsaz, N.; Banihabib, M. E. 2015. Comparison of different multi criteria decision-making models in prioritizing flood management alternatives, Water Resources Management 29(8): 2503-2525.

http://dx.doi.org/10.1007/s11269-015-0954-6

Choi, D. J.; Park, H. 2001. Analysis of water privatization scenarios in Korea with multi-criteria decision-making techniques, Journal of Water Supply Research and TechnologyAQUA 50(6): 335-352.

Chou, C.-C. 2009. Integrated short-term and long-term MCDM model for solving location selection problems, Journal of Transportation Engineering-ASCE 135(11): 880-893. http://dx.doi.org/10.1061/(ASCE)TE.1943-5436.0000057

Chou, J.-S.; Chen, H.-M.; Hou, C.-C.; Lin, C. W. 2010. Visualized EVM system for assessing project performance, Automation in Construction 19(5 SI): 596-607.

Chung, E.-S.; Lee, K. S. 2009. Identification of spatial ranking of hydrological vulnerability using multi-criteria decision making techniques: case study of Korea, Water Resources Management 23(12): 2395-2416. http://dx.doi.org/10.1007/s11269-008-9387-9

Dejus, T.; Antucheviciene, J. 2013. Assessment of health and safety solutions at a construction site, Journal of Civil Engineering and Management 19(5): 728-737. http://dx.doi.org/10.3846/13923730.2013.812578

Do, J.-Y.; Kim, D.-K. 2012. AHP-based evaluation model for optimal selection process of patching materials for concrete repair: focused on quantitative requirements, International Journal of Concrete Structures and Materials 6(2): 87-100. http://dx.doi.org/10.1007/s40069-012-0009-9

Duckstein, L.; Bobee, B.; Ashkar, F. 1991. A multiple criteria decision modeling approach to selection of estimation techniques for fitting extreme floods, Stochastic Hydrology and Hydraulics 5(3): 227-238. http://dx.doi.org/10.1007/BF01544059

Duckstein, L.; Treichel, W.; Elmagnouni, S. 1994. Ranking groundwater-management alternatives by multicriterion analysis, Journal of Water Resources Planning and Management-ASCE 120(4): 546-565.

http://dx.doi.org/10.1061/(ASCE)0733-9496(1994)120:4(546)

Ebrahimian, A.; Ardeshir, A.; Rad, I. Z.; Ghodsypour, S. H. 2015. Urban stormwater construction method selection using a hybrid multi-criteria approach, Automation in Construction 58: 118-128. http://dx.doi.org/10.1016/j.autcon.2015.07.014

Ehrgott, M.; Figueira, J. R.; Greco, S. 2010. Trends in multiple criteria decision analysis. New York: Springer. http://dx.doi.org/10.1007/978-1-4419-5904-1 
Emovon, I.; Norman, R. A.; Murphy, A. J.; Pazouki, K. 2015. An integrated multicriteria decision making methodology using compromise solution methods for prioritising risk of marine machinery systems, Ocean Engineering 105: 92-103. http://dx.doi.org/10.1016/j.oceaneng.2015.06.005

Figueira, J. R.; Greco, S.; Ehrgott, M. (Eds.) 2005. Multiple criteria decision analysis: state of the art surveys. Berlin: Springer. http://dx.doi.org/10.1007/b100605

Formisano, A.; Mazzolani, F. M. 2015. On the selection by MCDM methods of the optimal system for seismic retrofitting and vertical addition of existing buildings, Computers \& Structures 159(1-13). http://dx.doi.org/10.1016/j.compstruc.2015.06.016

Geng, G.; Wardlaw, R. 2013. Application of multi-criterion decision making analysis to integrated water resources management, Water Resources Management 27(8): 3191-3207. http://dx.doi.org/10.1007/s11269-013-0343-y

Gercek, H.; Karpak, B.; Kilincaslan, T. 2004. A multiple criteria approach for the evaluation of the rail transit networks in Istanbul, Transportation 31(2): 203-228.

http://dx.doi.org/10.1023/B:PORT.0000016572.41816.d2

Goicoechea, A.; Stakhiv, E. Z.; Li, F. 1992. Experimental evaluation of multiple criteria decision-models for application to water-resources planning, Water Resources Bulletin 28(1): 89102. http://dx.doi.org/10.1111/j.1752-1688.1992.tb03156.x

Govindan, K.; Rajendran, S.; Sarkis, J.; Murugesan, P. 2015. Multi criteria decision making approaches for green supplier evaluation and selection: a literature review, Journal of Cleaner Production 98: 66-83.

http://dx.doi.org/10.1016/j.jclepro.2013.06.046

Hanaoka, S.; Kunadhamraks, P. 2009. Multiple criteria and fuzzy based evaluation of logistics performance for intermodal transportation, Journal of Advanced Transportation 43(2): 123-153. http://dx.doi.org/10.1002/atr.5670430204

Hao, F.; Chen, G. 2010. A fuzzy multi-criteria group decisionmaking model based on weighted borda scoring method for watershed ecological risk management: a case study of three Gorges Reservoir Area of China, Water Resources Management 24(10): 2139-2165.

http://dx.doi.org/10.1007/s11269-009-9544-9

Hernandez, E. A.; Uddameri, V. 2010. Selecting agricultural best management practices for water conservation and quality improvements using atanassov's intuitionistic fuzzy sets, Water Resources Management 24(15): 4589-4612. http://dx.doi.org/10.1007/s11269-010-9681-1

Kabak, M.; Kose, E.; Kirilmaz, O.; Burmaoglu, S. 2014. A fuzzy multi-criteria decision making approach to assess building energy performance, Energy and Buildings 72: 382-389. http://dx.doi.org/10.1016/j.enbuild.2013.12.059

Kabir, G.; Sadiq, R.; Tesfamariam, S. 2014. A review of multi-criteria decision-making methods for infrastructure management, Structure and Infrastructure Engineering 10(9): 11761210. http://dx.doi.org/10.1080/15732479.2013.795978

Karamouz, M.; Ahmadi, A.; Yazdi, M. S. S.; Ahmadi, B. 2014. Economic assessment of water resources management strategies, Journal of Irrigation and Drainage Engineering 140(1). http://dx.doi.org/10.1061/(asce)ir.1943-4774.0000654

Karamouz, M.; Zahraie, B.; Araghinejad, S. 2005. Decision support system for monthly operation of hydropower reser- voirs: a case study, Journal of Computing in Civil Engineering 19(2): 194-207.

http://dx.doi.org/10.1061/(ASCE)0887-3801(2005)19:2(194)

Karamouz, M.; Zahraie, B.; Kerachian, R. 2003. Development of a master plan for water pollution control using MCDM techniques: a case study, Water International 28(4): 478-490. http://dx.doi.org/10.1080/02508060308691725

Kaya, I.; Kahraman, C. 2014. A comparison of fuzzy multicriteria decision making methods for intelligent building assessment, Journal of Civil Engineering and Management 20(1): 59-69. http://dx.doi.org/10.3846/13923730.2013.801906

Khelifi, F.; Lodolo, A.; Vranes, S.; Centi, G.; Miertus, S. 2006. A web-based decision support tool for groundwater remediation technologies selection, Journal of Hydroinformatics 8(2): 91-100.

Kildiene, S.; Zavadskas, E. K.; Tamosaitiene, J. 2014. Complex assessment model for advanced technology deployment, Journal of Civil Engineering and Management 20(2): 280290. http://dx.doi.org/10.3846/13923730.2014.904813

Kim, Y.; Chung, E.-S.; Jun, S.-M. 2015. Iterative framework for robust reclaimed wastewater allocation in a changing environment using multi-criteria decision making, Water Resources Management 29(SI2): 295-311.

http://dx.doi.org/10.1007/s11269-014-0891-9

Kumar, T.; Gautam, A. K.; Kumar, T. 2014. Appraising the accuracy of GIS-based multi-criteria decision making technique for delineation of groundwater potential zones, Water Resources Management 28(13): 4449-4466.

http://dx.doi.org/10.1007/s11269-014-0663-6

Kumru, M.; Kumru, P. Y. 2014. Analytic hierarchy process application in selecting the mode of transport for a logistics company, Journal of Advanced Transportation 48(8): 974999. http://dx.doi.org/10.1002/atr.1240

Kuo, M.-S. 2011. A novel interval-valued fuzzy MCDM method for improving airlines' service quality in Chinese CrossStrait Airlines, Transportation Research Part E-Logistics and Transportation Review 47(6): 1177-1193. http://dx.doi.org/10.1016/j.tre.2011.05.007

Kursunoglu, N.; Onder, M. 2015. Selection of an appropriate fan for an underground coal mine using the Analytic Hierarchy Process, Tunnelling and Underground Space Technology 48: 101-109. http://dx.doi.org/10.1016/j.tust.2015.02.005

Lashgari, A.; Fouladgar, M. M.; Yazdani-Chamzini, A.; Skibniewski, M. J. 2011. Using an integrated model for shaft sinking method selection, Journal of Civil Engineering and Management 17(4): 569-580.

http://dx.doi.org/10.3846/13923730.2011.628687

Lee, Y. W.; Dahab, M. F.; Bogardi, I. 1994. Fuzzy decisionmaking in-ground water nitrate risk management, Water Resources Bulletin 30(1): 135-148. http://dx.doi.org/10.1111/j.1752-1688.1994.tb03280.x

Levy, J. K. 2005. Multiple criteria decision making and decision support systems for flood risk management, Stochastic Environmental Research and Risk Assessment 19(6): 438-447. http://dx.doi.org/10.1007/s00477-005-0009-2

Li, F.; Phoon, K. K.; Du, X.; Zhang, M. J. 2013. Improved AHP method and its application in risk identification, Journal of Construction Engineering and Management-ASCE 139(3): 312-320.

http://dx.doi.org/10.1061/(ASCE)CO.1943-7862.0000605 
Li, X.; Wang, B.; Mehrotra, R.; Sharma, A.; Wang, G. L. 2009. Consideration of trends in evaluating inter-basin water transfer alternatives within a fuzzy decision making framework, Water Resources Management 23(15): 3207-3220. http://dx.doi.org/10.1007/s11269-009-9430-5

Lin, S. C. J.; Ali, A. S.; Bin Alias, A. 2015. Analytic hierarchy process decision-making framework for procurement strategy selection in building maintenance work, Journal of Performance of Constructed Facilities 29(2).

http://dx.doi.org/10.1061/(ASCE)CF.1943-5509.0000529

Machiwal, D.; Jha, M. K.; Mal, B. C. 2011. Assessment of groundwater potential in a semi-arid region of India using remote sensing, GIS and MCDM techniques, Water Resources Management 25(5): 1359-1386.

http://dx.doi.org/10.1007/s11269-010-9749-y

Madani, K.; Read, L.; Shalikarian, L. 2014. Voting under uncertainty: a stochastic framework for analyzing group decision making problems, Water Resources Management 28(7): 1839-1856. http://dx.doi.org/10.1007/s11269-014-0556-8

Mardani, A.; Jusoh, A.; Zavadskas, E. K. 2015a. Fuzzy multiple criteria decision-making techniques and applications - two decades review from 1994 to 2014, Expert Systems with Applications 42: 4126-4148. http://dx.doi.org/10.1016/j.eswa.2015.01.003

Mardani, A.; Jusoh, A.; Zavadskas, E. K.; Cavallaro, K.; Khalifah, Z. 2015b. Sustainable and renewable energy: An overview of the application of multiple criteria decision making techniques and approaches, Sustainability 7(10): 13947-13984. http://dx.doi.org/10.3390/su71013947

Marzouk, M.; Amer, O.; El-Said, M. 2013. Feasibility study of industrial projects using SIMOS' procedure, Journal of Civil Engineering and Management 19(1): 59-68. http://dx.doi.org/10.3846/13923730.2012.734855

Medineckiene, M.; Bjork, F. 2011. Owner preferences regarding renovation measures - the demonstration of using multicriteria decision making, Journal of Civil Engineering and Management 17(2): 284-295.

http://dx.doi.org/10.3846/13923730.2011.582380

Medineckiene, M.; Zavadskas, E. K.; Bjork, F.; Turskis, Z. 2015. Multi-criteria decision-making system for sustainable building assessment/certification, Archives of Civil and Mechanical Engineering 15(1): 11-18.

http://dx.doi.org/10.1016/j.acme.2014.09.001

Medineckiene, M.; Zavadskas, E. K.; Turskis, Z. 2011. Dwelling selection by applying fuzzy game theory, Archives of Civil and Mechanical Engineering 11(3): 681-697. http://dx.doi.org/10.1016/S1644-9665(12)60109-5

Netto, O. C.; Parent, E.; Duckstein, L. 1996. Multicriterion design of long-term water supply in Southern France, Journal of Water Resources Planning and Management-ASCE 122(6): 403-413.

http://dx.doi.org/10.1061/(ASCE)0733-9496(1996)122:6(403)

Palevicius, V.; Paliulis, G. M.; Venckauskaite, J.; Vengrys, B. 2013. Evaluation of the requirement for passenger car parking spaces using multi-criteria methods, Journal of Civil Engineering and Management 19(1): 49-58.

http://dx.doi.org/10.3846/13923730.2012.727463

Pinter, U.; Psunder, I. 2013. Evaluating construction project success with use of the M-TOPSIS Method, Journal of Civil Engineering and Management 19(1): 16-23. http://dx.doi.org/10.3846/13923730.2012.734849
Pons, O.; Aguado, A. 2012. Integrated value model for sustainable assessment applied to technologies used to build schools in Catalonia, Spain, Building and Environment 53: 49-58. http://dx.doi.org/10.1016/j.buildenv.2012.01.007

Pons, O.; De La Fuente, A. 2013. Integrated sustainability assessment method applied to structural concrete columns, Construction and Building Materials 49: 882-893. http://dx.doi.org/10.1016/j.conbuildmat.2013.09.009

Qi, H.; Qi, P.; Altinakar, M. S. 2013. GIS-based spatial Monte Carlo analysis for integrated flood management with two dimensional flood simulation, Water Resources Management 27(10): 3631-3645. http://dx.doi.org/10.1007/s11269-013-0370-8

Raju, K. S.; Duckstein, L. 2004. Integrated application of cluster and multicriterion analysis for ranking water resources planning strategies: a case study in Spain, Journal of Hydroinformatics 6(4): 295-307.

Raju, K. S.; Duckstein, L.; Arondel, C. 2000. Multicriterion analysis for sustainable water resources planning: a case study in Spain, Water Resources Management 14(6): 435-456. http://dx.doi.org/10.1023/A:1011120513259

Raju, K. S.; Kumar, D. N. 2006. Ranking irrigation planning alternatives using data envelopment analysis, Water Resources Management 20(4): 553-566.

http://dx.doi.org/10.1007/s11269-006-3090-5

Roozbahani, A.; Zahraie, B.; Tabesh, M. 2012. PROMETHEE with Precedence Order in the Criteria (PPOC) as a new group decision making aid: an application in urban water supply management, Water Resources Management 26(12): 3581-3599. http://dx.doi.org/10.1007/s11269-012-0091-4

Rousta, B. A.; Araghinejad, S. 2015. Development of a multi criteria decision making tool for a water resources decision support system, Water Resources Management 29(15): 57135727. http://dx.doi.org/10.1007/s11269-015-1142-4

Ruzgys, A.; Volvaciovas, R.; Ignatavicius, C.; Turskis, Z. 2014. Integrated evaluation of external wall insulation in residential buildings using SWARA-TODIM MCDM method, Journal of Civil Engineering and Management 20(1): 103-110. http://dx.doi.org/10.3846/13923730.2013.843585

Shafike, N. G.; Duckstein, L; Maddock, T. 1992. Multicriterion analysis of groundwater contamination management, Water Resources Bulletin 28(1): 33-43. http://dx.doi.org/10.1111/j.1752-1688.1992.tb03152.x

Shahriar, A.; Modirzadeh, M.; Sadiq, R.; Tesfamariam, S. 2012. Seismic induced damageability evaluation of steel buildings: a fuzzy-TOPSIS method, Earthquakes and Structures 3(5): 695-717. http://dx.doi.org/10.12989/eas.2012.3.5.695

Shelton, J.; Medina, M. 2010. Integrated multiple-criteria decision-making method to prioritize transportation projects, Transportation Research Record 2174: 51-57. http://dx.doi.org/10.3141/2174-08

Shiue, Y-Ch.; Lin, Ch-Y. 2012. Applying analytic network process to evaluate the optimal recycling strategy in upstream of solar energy industry, Energy and Buildings 54: 266-277. http://dx.doi.org/10.1016/j.enbuild.2012.07.032

Siozinyte, E.; Antucheviciene, J. 2013. Solving the problems of daylighting and tradition continuity in a reconstructed vernacular building, Journal of Civil Engineering and Management 19(6): 873-882.

http://dx.doi.org/10.3846/13923730.2013.851113 
Siozinyte, E.; Antucheviciene, J.; Kutut, V. 2014. Upgrading the old vernacular building to contemporary norms: multiple criteria approach, Journal of Civil Engineering and Management 20(2): 291-298.

http://dx.doi.org/10.3846/13923730.2014.904814

Sobanjo, J. O; Stukhart, G.; James, R.W. 1994. Evaluation of projects for rehabilitation of highway bridges, Journal of Structural Engineering-ASCE 120(1): 81-99.

http://dx.doi.org/10.1061/(ASCE)0733-9445(1994)120:1(81)

Soyguder, S.; Alli, H. 2009. An expert system for the humidity and temperature control in HVAC systems using ANFIS and optimization with fuzzy modeling approach, Energy and Buildings 41(8): 814-822.

http://dx.doi.org/10.1016/j.enbuild.2009.03.003

Staniunas, M.; Medineckiene, M.; Zavadskas, E. K.; Kalibatas, D. 2013. To modernize or not: ecological-economical assessment of multi-dwelling houses modernization, Archives of Civil and Mechanical Engineering 13(1): 88-98.

http://dx.doi.org/10.1016/j.acme.2012.11.003

Su, H.-T.; Tung, Y.-K. 2014. Multi-criteria decision making under uncertainty for flood mitigation, Stochastic Environmental Research and Risk Assessment 28(7): 1657-1670. http://dx.doi.org/10.1007/s00477-013-0818-7

Susinskas, S.; Zavadskas, E. K.; Turskis, Z. 2011. Multiple criteria assessment of pile-columns alternatives, Baltic Journal of Road and Bridge Engineering 6(3): 145-152.

http://dx.doi.org/10.3846/bjrbe.2011.19

Tamosaitiene, J.; Gaudutis, E. 2013. Complex assessment of structural systems used for high-rise buildings, Journal of Civil Engineering and Management 19(2): 305-317. http://dx.doi.org/10.3846/13923730.2013.772071

Tanadtang, P.; Park, D.; Hanaoka, S. 2005. Incorporating uncertain and incomplete subjective judgments into the evaluation procedure of transportation demand management alternatives, Transportation 32(6): 603-626.

http://dx.doi.org/10.1007/s11116-005-0645-x

Tarlochan, F.; Samer, F.; Hamouda, A. M. S.; Ramesh, S.; Khalid, K. 2013. Design of thin wall structures for energy absorption applications: enhancement of crashworthiness due to axial and oblique impact forces, Thin-Walled Structures 71: 7-17. http://dx.doi.org/10.1016/j.tws.2013.04.003

Tecle, A. 1992. Selecting a multicriterion decision-making technique for watershed resources management, Water Resources Bulletin 28(1): 129-140.

http://dx.doi.org/10.1111/j.1752-1688.1992.tb03159.x

Teng, J.-Y.; Huang, W.-C.; Lin, M.-C. 2010. Systematic budget allocation for transportation construction projects: a case in Taiwan. Transportation 37(2): 331-361. http://dx.doi.org/10.1007/s11116-009-9239-3

Terracciano, G.; Di Lorenzo, G.; Formisano, A.; Landolfo, R. 2015. Cold-formed thin-walled steel structures as vertical addition and energetic retrofitting systems of existing masonry buildings, European Journal of Environmental and Civil Engineering 19(7): 850-866.

http://dx.doi.org/10.1080/19648189.2014.974832

Tesfamariam, S.; Sadiq, R. 2006. Risk-based environmental decision-making using Fuzzy Analytic Hierarchy Process (F-AHP), Stochastic Environmental Research and Risk Assessment 21(1): 35-50.

http://dx.doi.org/10.1007/s00477-006-0042-9
Ulubeyli, S.; Kazaz, A. 2009. A multiple criteria decision-making approach to the selection of concrete pumps, Journal of Civil Engineering and Management 15(4): 369-376.

http://dx.doi.org/10.3846/1392-3730.2009.15.369-376

Um, I. S.; Cheon, H. J.; Lee, H. C. 2011. A simulation-based optimal design and analysis method for designing a train overhaul maintenance facility, Proceedings of the Institution of Mechanical Engineers Part F-Journal of Rail and Rapid Transit 225(F5): 523-539.

http://dx.doi.org/10.1243/09544097JRRT309

Vamvakeridou-Lyroudia, L. S.; Savic, D. A.; Walters, G. A. 2006. Fuzzy hierarchical decision support system for water distribution network optimization, in 8th International Conference on Computing and Control for the Water Industry, Civil Engineering and Environmental Systems 23(3): 237-261. http://dx.doi.org/10.1080/10286600600789706

Verma, M.; Rajasankar, J.; Anandavalli, N.; Prakash, A.; Iyer, N. R. 2015. Fuzzy similarity approach for ranking and health assessment of towers based on visual inspection, Advances in Structural Engineering 18(9): 1399-1414.

http://dx.doi.org/10.1260/1369-4332.18.9.1399

Wang, Y.; Deng, X.; Marcucci, D. J.; Le, Y. E. 2013. Sustainable development planning of protected areas near cities: case study in China, Journal of Urban Planning and DevelopmentASCE 139(2): 133-143. http://dx.doi.org/10.1061/(ASCE)UP.1943-5444.0000133

Wiecek, M. M.; Ehrgott, M.; Fadel, G.; Figueira, J. R. 2008. Multiple criteria decision making for engineering, Omega 36: 337-339. http://dx.doi.org/10.1016/j.omega.2006.10.001

Woldt, W.; Bogardi, I. 1992. Ground-water monitoring network design using multiple criteria decision-making and geostatistics, Water Resources Bulletin 28(1): 45-62. http://dx.doi.org/10.1111/j.1752-1688.1992.tb03153.x

Wong, J.; Li, H.; Lai, J. 2008a. Evaluating the system intelligence of the intelligent building systems - Part 1: development of key intelligent indicators and conceptual analytical framework, Automation in Construction 17(3): 284-302. http://dx.doi.org/10.1016/j.autcon.2007.06.002

Wong, J.; Li, H.; Lai, J. 2008b. Evaluating the system intelligence of the intelligent building systems - Part 2: construction and validation of analytical models, Automation in Construction 17(3): 303-321.

http://dx.doi.org/10.1016/j.autcon.2007.06.003

Yakar, F.; Celik, F. 2014. A highway alignment determination model incorporating GIS and multi-criteria decision making, KSCE Journal of Civil Engineering 18(6): 1847-1857. http://dx.doi.org/10.1007/s12205-014-0130-1

Yazdani-Chamzini, A.; Yakhchali, S. H. 2012. Tunnel boring machine (TBM) selection using fuzzy multicriteria decision making methods, Tunnelling and Underground Space Technology 30: 194-204.

http://dx.doi.org/10.1016/j.tust.2012.02.021

Zagorskas, J.; Zavadskas, E. K.; Turskis, Z.; Burinskiene, M.; Blumberga, A.; Blumberga, D. 2014. Thermal insulation alternatives of historic brick buildings in Baltic Sea region, Energy and Buildings 78: 35-42. http://dx.doi.org/10.1016/j.enbuild.2014.04.010

Zak, J. 2011. The methodology of multiple criteria decision making/aiding in public transportation, Journal of Advanced Transportation 45(1): 1-20. http://dx.doi.org/10.1002/atr.108 
Zarghami, M.; Szidarovszky, F. 2009. Stochastic-fuzzy multi criteria decision making for robust water resources management, Stochastic Environmental Research and Risk Assessment 23(3): 329-339.

http://dx.doi.org/10.1007/s00477-008-0218-6

Zavadskas, E. K.; Antucheviciene, J.; Kapliński, O. 2015. Multicriteria decision making in civil engineering: Part I - a stateof-the- art survey, Engineering Structures and Technologies 7(3): 103-113.

Zavadskas, E. K.; Antucheviciene, J. 2007. Multiple criteria evaluation of rural building's regeneration alternatives, Building and Environment 42(1): 436-451.

http://dx.doi.org/10.1016/j.buildenv.2005.08.001

Zavadskas, E. K.; Susinskas, S.; Daniunas, A.; Turskis, Z.; Sivilevicius, H. 2012. Multiple criteria selection of pile-column construction technology, Journal of Civil Engineering and Management 18(6): 834-842.

http://dx.doi.org/10.3846/13923730.2012.744537
Zavadskas, E. K.; Turskis, Z. 2011. Multiple criteria decision making (MCDM) methods in economics: an overview, Technological and Economic Development of Economy 17(2): 397-427. http://dx.doi.org/10.3846/20294913.2011.593291

Zavadskas, E. K.; Turskis, Z.; Tamosaitiene, J. 2011. Selection of construction enterprises management strategy based on the SWOT and Multi-Criteria Analysis, Archives of Civil and Mechanical Engineering 11(4): 1063-1082. http://dx.doi.org/10.1016/S1644-9665(12)60096-X

Zavadskas, E. K.; Turskis, Z.; Vilutiene, T. 2010. Multiple criteria analysis of foundation instalment alternatives by applying Additive Ratio Assessment (ARAS) Method, Archives of Civil and Mechanical Engineering 10(3): 123-141. http://dx.doi.org/10.1016/S1644-9665(12)60141-1

Zavadskas, E. K.; Vilutiene, T.; Turskis, Z.; Saparauskas, J. 2014. Multi-criteria analysis of projects' performance in construction, Archives of Civil and Mechanical Engineering 14(1): 114-121. http://dx.doi.org/10.1016/j.acme.2013.07.006

Edmundas Kazimieras ZAVADSKAS is Professor, Head of the Department of Construction Technology and Management at Vilnius Gediminas Technical University, Vilnius, Lithuania, and a chief researcher at Research Institute of Smart Buildings Technologies. He has a PhD in building structures (1973) and DrSc (1987) in building technology and management. He is a member of the Lithuanian and several foreign Academies of Sciences. He is Doctor Honoris Causa at Poznan, Saint-Petersburg, and Kiev universities. He is Editor in Chief and a member of editorial boards of a number of research journals. He is author and co-author of more than 500 papers and a number of monographs. Research interests are: building technology and management, decisionmaking theory, automation in design and decision support systems.

Oleg KAPLIŃSKI is Professor of Civil Engineering at Faculty of Architecture (IAP), Poznan University of Technology, Poznan, Poland. He lectures economics and organization of the investment process, as well as the theory and principles of work places design. The author of 240 publications. Doctor Honoris Causa of VGTU (1996). Member of the CE Committee of the Polish Academy of Sciences. His current research are: an integral management, integral design, risk management, theory of decision making and research methods in $\mathrm{CE}$ and architecture.

Jurgita ANTUCHEVIČIENÉ is Professor at the Department of Construction Technology and Management at Vilnius Gediminas Technical University, Vilnius, Lithuania. She received a PhD in Civil Engineering in 2005. She is author and co-author of about 80 scientific papers. Research interests include: multiple criteria analysis, decision-making theories and decision support systems, sustainable development, construction management and investment. 